\section{Review of Leafhopper (Empoasca flavescens): A Ma- jor Pest in Castor (Ricinus communis)}

Kwadwo Gyapong Agyenim-Boateng , Jian-nong Lu , Yu-zhen Shi and Xue-gui Yin*

Department of Crop Breeding and Genetics, College of Agricultural Sciences, Guangdong Ocean University, Zhanjiang 524088, China

\begin{abstract}
Castor is an important oilseed crop. The castor bean contains about $50-55 \%$ oil. Among vegetable oils, castor oil is distinguished by its high content (over $85 \%$ ) of ricinoleic acid. No other vegetable oil contains so high proportion of fatty hydroxy acids. Castor oil's unsaturated bond, high molecular weight (298), low melting point $\left(5^{\circ} \mathrm{C}\right)$ and very low solidification point $\left(-12^{\circ} \mathrm{C}\right.$ to $\left.-18^{\circ} \mathrm{C}\right)$ makes it industrially useful, most of all for the highest and most stable viscosity of any vegetable oil. The castor plant has a substantial taproot with many lateral branches which can reach a great depth enabling them to withstand drought and most harsh weather conditions. Leaves of castor plants are large, glossy and green with pointed lobes and prominent veins; each develops on a long stalk often used as feed for livestock and others animals, especially the economy booster, eri-silkworm. However, the castor leaf for many years has often been attacked by the leafhopper and in most cases leads to the destruction of the plant. The leafhopper causes hopperburn which renders the attacked leaves dry, uneven, curl downward in the shape of an inverted boat, margins turn brown and eventually death of the plant. The study of the makeup, life cycle and characteristics of this insect is of much importance to castor farmers, breeders and geneticists.
\end{abstract}

${ }^{*}$ Corresponding author: Yin Xuegui, Agricultural College, Guangdong Ocean University, Haida Road, Mazhang District, Zhanjiang 524088, Guangdong, China, Tel: +86 07592383246; E-mail: yinxuegui@126.com

Citation: Agyenim-Boateng KG, Lu JN, Shi YZ, Yin XG (2018) Review of Leafhopper (Empoasca flavescens): A Major Pest in Castor (Ricinus communis). J Genet Genomic Sci 3: 009.

Received: May 16, 2018; Accepted: June 13, 2018; Published: June 29, 2018

Copyright: (C 2018 Agyenim-Boateng KG et al., This is an open-access article distributed under the terms of the Creative Commons Attribution License, which permits unrestricted use, distribution, and reproduction in any medium, provided the original author and source are credited.
An in-depth understanding of the mechanism of leafhoppers and methods of controlling them will aid in the reduction of their population if obliteration is not possible.

Keywords: Castor (Ricinus communis); Hopperburn; Leafhopper (Empoasca flavescens); Wax bloom

\section{Introduction}

Castor (Ricinus communis) from the family Euphorbiaceae is an important industrially valued nonedible oilseed crop [1]. It is widely distributed and adapted throughout the tropics, subtropics and temperate areas due to its low demand on soil fertility, requirement of moderate rainfall, less competition with other food crops and food grade oils. It is high yielding, and both varieties and hybrids are bred for cultivation in different agro-ecological niches with yields of around $800-1000 \mathrm{~kg} / \mathrm{ha}$ under rainfed conditions and $1600-2000 \mathrm{~kg} / \mathrm{ha}$ under irrigated conditions [2]. Castor is grown for its seeds, which is extracted for the non-edible oil mainly used in the manufacturing of paints, lubricants, soaps, hydraulic brake fluids, polymers and perfumery products, among others; several derivatives of castor oil are used in a variety of industries [3]. Castor oil is the only vegetable oil that contains up to $85 \%$ of the unique hydroxy fatty acid, ricinoleic acid, which confers distinctive industrial properties to the oil $[4,5]$. Castor oil has more than 700 industrial uses, and its global demand is constantly rising at $3-5 \%$ per annum $[6,7]$.

India is the world leader in castor, producing nearly two-thirds of the total global production followed by Brazil and China $[1,8]$. The instabilities in the productivity of castor in India are generally caused by two main reasons: first, it is grown as a rain-fed crop, and as a long-duration crop is subject to the vagaries of the monsoon; second, it attracts a large number of pests [9]. Castor is attacked by insect pests right from sowing to harvesting. More than 60 species of insects and mites have been reported to cause damage to the castor crop and their related yield loss has been estimated to be about 40-89\% [1012]. The seed yield losses in castor due to insect pests varied with the season, the severity of the pest and the hybrid variety of the plant [13]. The sucking pests such as leafhoppers (Empoasca flavescens), whiteflies and thrips have been known to be the most important pests attacking castor resulting in excessive loss of grain yield [14]. 14$15 \%$ of yield loss caused by sucking pests was recorded in Guajarat in India [15]. The nymphs and adults of the leafhopper suck sap from leaves and characteristic symptoms of hopperburn appear owing to the toxigenic nature of leafhopper [16].

\section{The Leafhopper (About the insect) (Empoasca fla- vescens Fabricius)}

\section{Taxonomy}

Phylum - Arthropoda

Class - Insecta

Sub-Order - Hemiptera

Family - Homoptera 


\section{Genus - Empoasca}

Species - Flavescens

Green leafhopper, Empoasca flavescens Fab., which appears as light green or greenish yellow nymphs and adults (Figure 1) is one of the severe sucking pests that suck sap from on and the under surface of leaves causing hopper burn. Cicada flavescens, as previously called, was first described by Fabricius in Germany in 1974 [17]. Later it was reported by other investigators as generally occurring throughout Europe and northern Africa on Atriplex, Chenopodium, Clematis, hop, potato, raspberry, sugar beet, and vines, and on many herbaceous plants and deciduous and coniferous trees [18]. This pest has been reported to be much injurious to young plants, sucking the juices to such an extent that the plants fade, curl and eventually die.

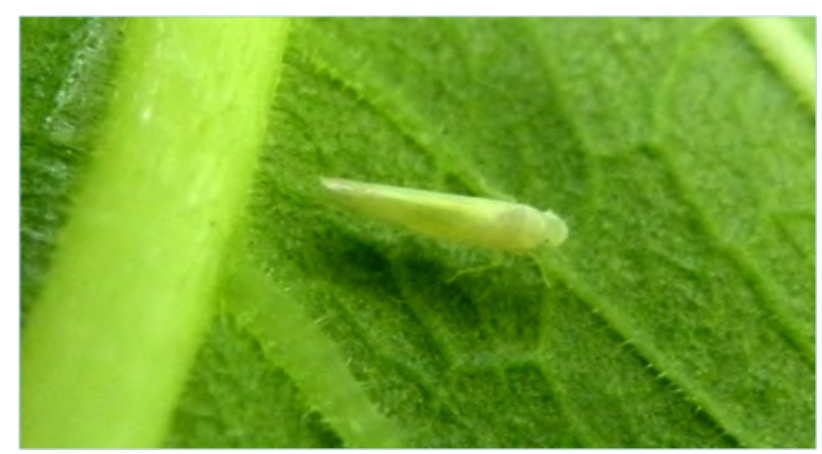

Figure 1: An image of the leafhopper (Empoasca flavescens)

Currently, this pest is widely distributed in the whole of Palearctic regions, United States of America, East Africa, Brazil, Ceylon, India, Great Britain and China. In India, it is supposed a major pest of tea in the North-Eastern parts and affects castor mostly in the Northern areas. It has been accused of producing a stunted growth on the plants attacked in India though there is not much work to prove that.

Leafhoppers also called jassids are small and less than $1 / 4$ inches in length as adults. The adults are small, wedge-shaped and pale green. The nymphs are yellowish green in color. They have a prolongated head with a smooth, flat, triangular structure with an antenna possessing the sensorial parts. The thorax is simple and abdomen is a narrowing posterior. There are two parallel rows of spines which extend all along the tibiae at the hind legs.

\section{The Life Cycle of the Insect}

The females scratch the leaf tissues and young stems and lay the eggs inside the veins and midribs of the leaves. A female can lay 15 to 37 eggs with an oviposition period of five to seven days. The egg hatches into nymph within 6 to 13 days (Figure 2), depending on the temperature. Compared to winter, the period of hatching in summer is longer. The nymph undergoes five instars and becomes adult in 8 to 22 days. The complete life cycle lasts for about 19 to 42 days. The average longevity of male adult is 9 days, whereas the female lives for 17 days. However, it has been recorded that an adult leafhopper may live up to 102 days. The insect remains active throughout the year, but maximum population growth occurs during November to January, that is mostly within the winter season. The life cycle of the leafhopper is described below in figure 2 from http://www.yourarticlelibrary.com/zoology/tea-green-fly-empoasca-flavescens-distribution-life-cycle-and-control/24048 [19].

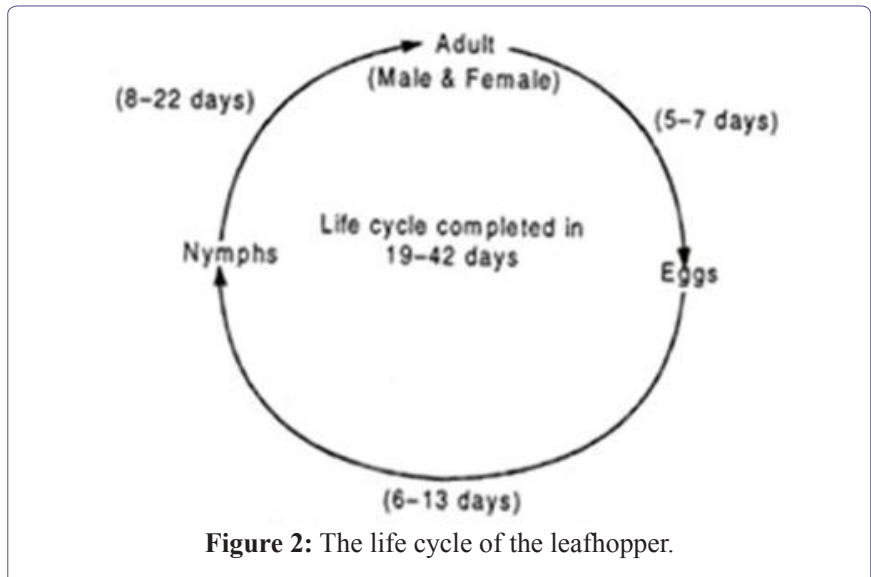

Although initially considered to be a minor or occasionally serious pest of tea, Empoasca flavescens has now been established as a regular and serious pest in tea plantations of sub-Himalayan North Bengal in India [20]. The leafhopper is also considered as a severe pest of castor, tea, okra, mulberry and many other crops [3,20-22].

\section{Hopperburn or Rim Blight}

Nymphs and adults of E. flavescens damage the plant by sucking the sap of young leaves and tender shoots. Attacked leaves become dry, uneven, curls downward in the shape of an inverted boat and their margins turn brown. This characteristic symptom is known as 'Rim Blight' or 'Hopperburn' (Figure 3).

The 'hopperburn' and other symptoms are caused mainly by interference with the translocation of food materials and water due to the physical plugging of the xylem and the destruction of the phloem cell [23].

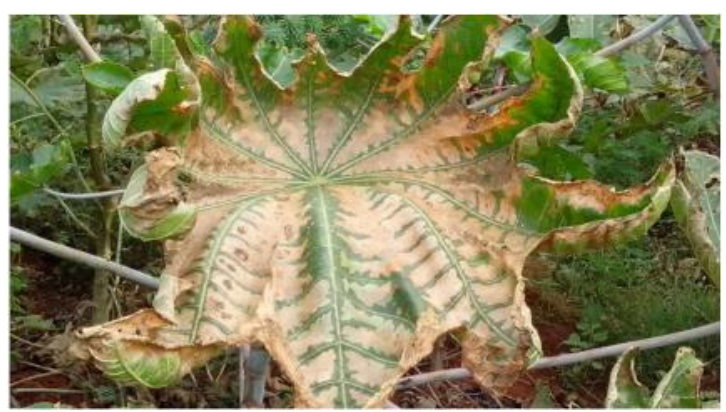

Figure 3: Image showing a castor leaf exhibiting the hopperburn symptom.

\section{Influence of Weather on the Incidence of Leafhop- per}

In an experiment by Patel et al., in analyzing the population dynamics of sucking pests with relation to the weather conditions, it was observed that the population of leafhopper increases as 
temperature and evening relative humidity decreases (Figure 4) [14]. This is to say that an increase in bright sunshine hours and morning relative humidity has a positive effect on the population.

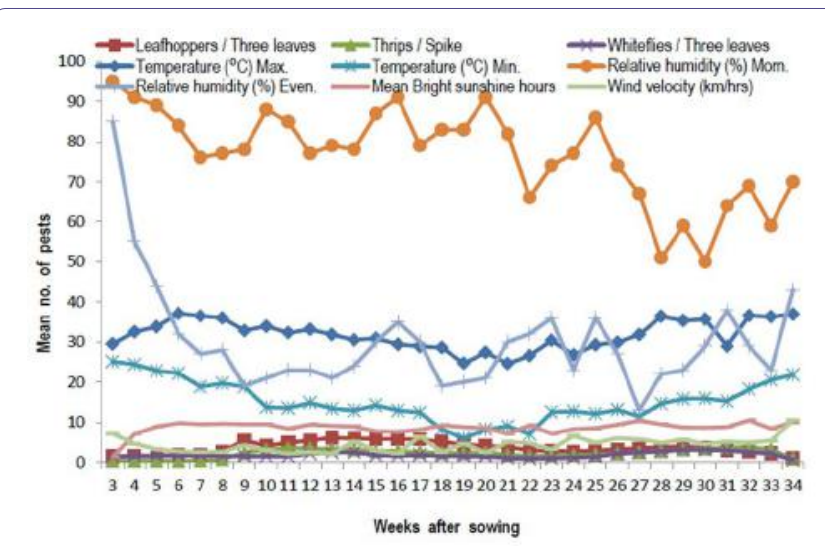

Figure 4: Seasonal incidence of sucking pests of castor in relation to abiotic factors.

Singh et al., in an experiment conducted in 1990 had a leafhopper population with significant positive association with maximum daily temperature and positive correlation with minimum temperature [24]. Jena and Kuila also reported that leafhopper infestation had a positive correlation with maximum temperature whereas it was negatively correlated with sunshine [25]. The variable effect of different weather parameters on the pest population might be due to the difference in phenology of the crop and time of appearance of the pest at different localities, where crops have been grown.

In an experiment by Laxman and Maheswari (Figure 5), on the effect of dates of sowing on incidence leafhopper on castor genotypes during kharif season 2013, it was revealed that incidence of leafhoppers was in general comparatively high in late sown crop than early sown crop [26]. When castor was sown early, the hopper burn scored was 2 with 11 to 25 percent injury on varieties DPC-9, DCS-9, PCH111, PCH-106 and Kranthi and whereas when the crop was sown late, maximum hopper burn score of 4 with more than 50 percent hopper injury was observed on DPC-9, DCS-9, PCH- 288, PCH-111, RG2835, PCH-106, PCH-222 and RG-2928.

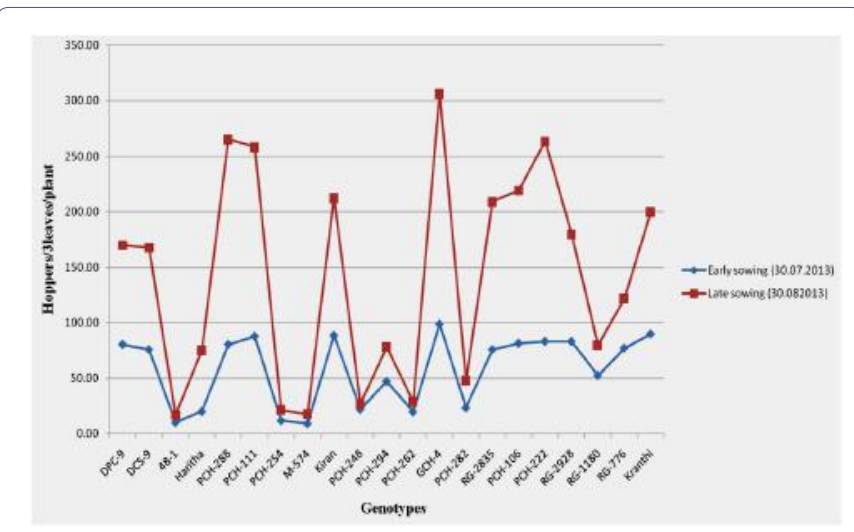

Figure 5: The incidence of leafhoppers on castor genotypes in early and late sowings.
These observations in the experiment above confirm work done by Akashe et al., Jayaraj and Basheer, Jayraj and APR castor [27-29].

The activity and multiplication of the leafhopper is enhanced in the cold and humid weather of the winter season. Mounica et al., also experimented in 2018 and indicated that the correlation studies on leafhopper population with abiotic factors showed that maximum temperature, minimum temperature, rainfall, number of rainy days and evaporation were negatively correlated but relative humidity and sunshine hours were positively correlated with leafhopper population [30-32].

Too much rain or dry weather is not favorable for the development of the insect $[33,34]$. Empoasca is most damaging during the period between the dry and rainy seasons [35].

A leafhopper population on castor had a significant positive correlation with the maximum temperature and a significant negative correlation with the morning Relative Humidity (RH) in an experiment conducted by Gaur [36]. Their findings conform to the reports of Jayasimha et al., [21] who reported that leafhopper population on okra exhibited positive correlation with the maximum temperature and negative correlation with RH. Srinivasan et al., also had similar observations in okra whereby within the environmental factors maximum temperature had a positive correlation with the density of leafhopper present [22].

\section{Waxy Bloom Presence in Castor}

Morphological characters of host plant serve as a non-preference mechanism for feeding and oviposition by insects [37]. Among the different morphological attributes, bloom character has been reported to be the most important in imparting resistance against the sucking pests [38]. Presence of wax bloom on the surface of plant parts could act as barriers to feeding by phytophagous insects [32]. The bloom character of castor is the presence of a wax coating on the plant (Figure 6), wholly or partially. Castor plants with wax coating on all parts of the plant are classified as triple bloom, the ones with bloom on the stem, fruits, on the lower (dorsal) side of the leaf, but not the upper surface (ventral) of the leaf are called double bloom and the ones with the wax coating on only the stem and not the leaves or fruits are described as single bloom. Studies have proven that the higher the bloom, the higher the resistance to pests [39,40]. Castor varieties with heavy, waxy bloom are more resistant to leafhoppers than bloomless types [41,42]. In Palem, Andhra Pradesh (India), castor plants with green stem and triple bloom were utterly free from leafhoppers [13]. No-bloom and single-bloom types are reported to be less resistant to leafhopper than double and triple-bloom types in castor [43-45].

Among 28 castor genotypes screened against leafhopper by Mounica et al., in 2018, castor cultivars, GCH-7, PCH-254 and SKI336 had the lowest leafhopper population and hopper burn scores while the genotypes DPC-9, DCH-177 recorded the highest leafhopper population with higher hopper burn scores [32]. This could be supported by the fact that GCH-7, PCH-254 and SKI-336 were triple bloom genotypes imparting resistance to the leafhopper by antixenotic mechanism while DPC-9, DCH-177 and PCH-111 were zero and single bloom genotypes respectively with no wax bloom on their leaf lamina making them susceptible to the leafhopper. In a similar experiment by, among the eight genotypes of castor experimented on, DCH-177 (single bloom) and DPC-9 were more preferred by the 
pests, while GCH-4 (triple bloom) and PCH-111 was least preferred [46]. The genotypes with zero and single bloom were susceptible to leafhopper and thrips. None of the genotypes with double and triple bloom character recorded high infestation of leafhopper and thrips. This research confirms most work done by earlier cited in this review. The bloom of castor is an essential trait in pest resistance (Figure 7).

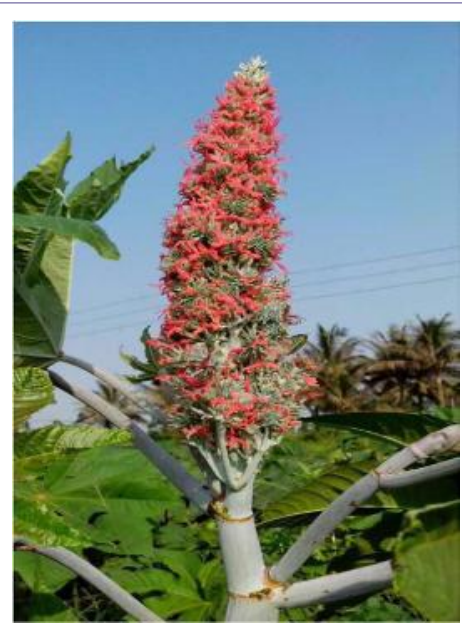

Figure 6: Main raceme and branch of castor plant with wax bloom.

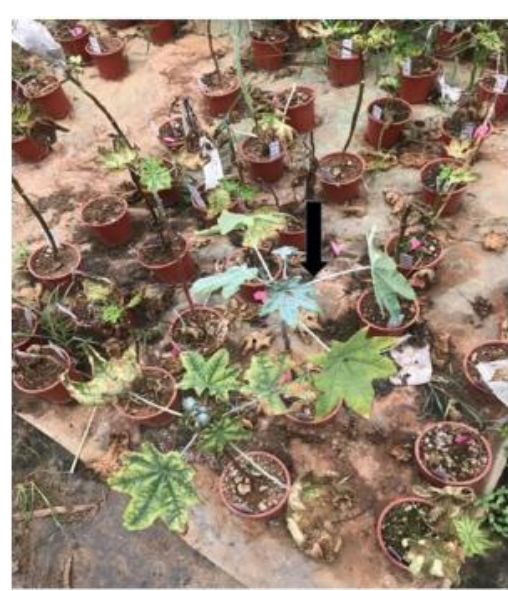

Figure 7: Image showing diseased plants hopper burned castor plants and resistant wax bloom plant (with arrow).

\section{Chemical Control of Empoasca flavescens and Its Side Effects}

Dichlorvos (DDVP), which has been banned since the 1980s in China, is a well-known chemical used in the combat of pests of mulberry like Empoasca flavescens [47-49]. The chemical, however, has been recorded to be highly toxic to the natural enemies of insect pests and aids the elimination of their entire population [50].

Recently an outbreak on mulberry by some sucking pests revealed that the most of the pests had developed resistance to the dichlorvos and apparent destruction of the natural enemies by the chemical [51].
Sakthivel et al., juxtaposed the effects of the commonly used chemical dichlorvos (DDVP-76EC) to some botanicals against leafhopper Empoasca flavescens F. infesting mulberry as well as their biosafety to natural enemies (Table 1) [51]. Among the botanicals, a single application of neem oil (3\%), FORS (2\%) and Pongamia oil $(3 \%)$ recorded $48.73,46.88$ and $42.49 \%$ reduction in leafhopper population respectively, whereas the NSKE (5\%) exhibited least among all $(33.59 \%$ at $1 \mathrm{DAS})$.

The synergistic effect of neem oil and FORS recorded the best, $72.64 \%$ reduction followed by Pongamia oil + FORS $(62.81 \%)$ and neem oil + Pongamia oil $(60.16 \%)$. Though dichlorvos proved active than all treatments $(88.57 \%$ reduction), the chemical also eliminated more than $90 \%$ population of predatory Coccinellids and spiders, but the botanicals found relatively safer. Hence, the combination of neem oil $(3 \%)$ with fish oil rosin soap $(2 \%)$ could be used as an alternate to dichlorvos to manage leafhopper menace in mulberry as well as to conserve the natural enemies.

Anjani et al., stated that although insecticide application is effective in controlling leafhoppers, the length of effective protection varies with an additional requirement of foliar insecticide sprays to control the pest, which eventually increases the cost of production [52].

\section{Intercropping as a Control Measure}

To control pests, farmers often use insecticides that are costly and detrimental to the environment. However intercropping is an alternative pest management strategy, which can reduce herbivorous pests by making the host-plants difficult to locate, or by increasing the effectiveness of the natural enemies [53]. Intercropping is an essential cultural practice in pest management which is based on the principle of reducing insect pests by increasing the diversity of an ecosystem [54]. Most studies indicated that diversification practices such as intercropping in pigeon pea and other crops are beneficial because these practices reduce pest damage $[55,56]$. The excessive branching property of castor gives a unique plant structure and makes it easy to manipulate the environment and intercrop castor with different intercrops for a potential reduction in the incidence of insect pests [9].

It is quite difficult for farmers who solely rely on rain-fed agriculture and without much financial support to adopt capital-intensive measures in plant protection. In this regard, intercropping becomes the most likely method to be chosen. That is why there is a strong need to develop pest management practices that are less expensive for resource-poor farmers. Hence, there is a significant need to develop a system that is diverse and less prone to pests and diseases.

Rao et al., in 2012, experimented on an intercropping system for controlling pests. From their experiment, it was seen that there was a diversity created by introducing cluster bean, cowpea, black gram, or groundnut as intercrops in castor which resulted in a buildup of natural enemies (Microplitis, coccinellids and spiders) of the major pests of castor [9]. Furthermore, suitable conditions for the growth of the pests were reduced.

As a result of the buildup of natural enemies, there was much less pest incidence and damage in castor intercropped with cluster bean, cowpea and groundnut compared to the castor monocrop. These intercropping systems by Rao et al., proved much more efficient with 
regards to equivalent yield and land equivalent ratio [9]. Economic analysis also showed that these intercropping systems were more profitable than planting castor alone. In conclusion, these systems, aside protecting the plant from pest attacks, resulted in high yields of all intercrops and higher economic returns.

In another experiment by Faselt (2014) to control the potato leafhopper (a key pest in alfalfa) in the Northeast United States, two crop treatments (alfalfa monocrop, alfalfa intercropped with orchard grass) were crossed with three predator treatments (no predator control, $\mathrm{Na}$ bis americoferus and Coleomegilla maculata) [53]. There was no effect of $C$. maculata on leafhopper abundance. By the end of the first week, $N$. americoferus significantly reduced leafhopper abundance, but only in the intercropped alfalfa. These results indicated that intercropping alfalfa with orchard grass enhanced the biological control of the potato leafhopper by $N$. americoferus.

In an effort to control tea green leafhopper Empoasca vitis Göthe in Southern China, Zhang et al., [57] intercropped tea with non-host plant Catsia tora (Fabaceae) as a cover crop. The intercropping of $C$. tora in the tea field markedly reduced the $E$. vitis population levels and promoted an increase in the natural enemies of this pest, such as spiders, coccinellids and lacewings.

In 2015, Rosmana et al., conducted an experiment on how intercropping can reduce the infestation of green leafhopper (Nephotettix virescens Distant) and white stem borer (Scirpophaga innotata Wlk.) on rice varieties in Indonesia [58]. The results of the experiment showed a lower incidence of the pests on rice in the intercropped systems than the monocropped plants. This indicated that intercropping had a positive effect on pest infestation and at the same time conserving farm traditional varieties that may be important for sustainable production, which deserves further experiment in castor.

\section{Resistant Cultivars}

Identification and use of resistant genotypes in breeding programme for the development of resistant varieties against the insect pests and their use in IPM (Integrated Pest Management) programmes is the most economical approach and would be inexpensive in long run because it minimizes the number of insecticides application, lessens the expenses involved in plant protection and conserves the natural enemies besides preserving the environmental safety [32]. Host-plant resistance is the most reliable, economical and eco-friendly measure to control leafhopper [52]. Seventeen Indian collections have been identified as stable sources of resistance against leafhopper $[38,59]$.

In an experiment conducted at the Guangdong Ocean University, China (yet to be published), during winter, a whole farm was infested with the leafhopper pest. Many materials were susceptible but Heyuan 1 and Heyuan 2, wild materials collected from the Guangdong Province, remained resistant. In that experiment, they were observed as very resistant and subsequent tests supported this finding.

It has however been seen that most of the plants resistant to this particular kind of pest have the waxy bloom. The use of resistant varieties in the IPM programmes is economical and eventually inexpensive as it reduces the application of insecticides, lessens the expenses involved in plant protection and conserves the natural enemies while keeping the safety of the environment [40]. The resistance to leafhopper is heritable and can be used in pest resistance breeding (Figure 8).

\section{Conclusion}

A healthy castor plant is of much importance in castor production. Many industries rely on castor as the raw material. Thus the demand for castor keeps rising. To meet the rising demands, every hindrance to the optimum production of castor must be dealt with accordingly. Empoasca flavescens is an obstacle to the growth of the castor plant and adversely affecting the secondary consumers of castor like the eri silkworm.

Much research has been done on these pests, and favorable methods and conditions have been assessed. Since most methods have proved beneficial, it is expedient that measures that are less harmful to the natural enemies and consumers are employed. However, research regarding the castor plant is limited, and castor research scientists are entreated to help in the fight against the leafhopper.

\begin{tabular}{|c|c|c|c|c|c|c|c|}
\hline \multirow{2}{*}{ Treatment } & \multicolumn{9}{|c|}{ Mean number of jassid per leaf } & Mulberry leaf yield \\
(gm/Plant)
\end{tabular}

Table 1: Effect of botanicals on the population of leafhopper Empoasca flavescens in mulberry.

PTC: Pre-Treatment Count; DAS: Days After Spray; NSKE: Neem Seed Kernel Extract; FORS: Fish Oil Rosin Soap; DDVP-76EC: Dichlorvos 


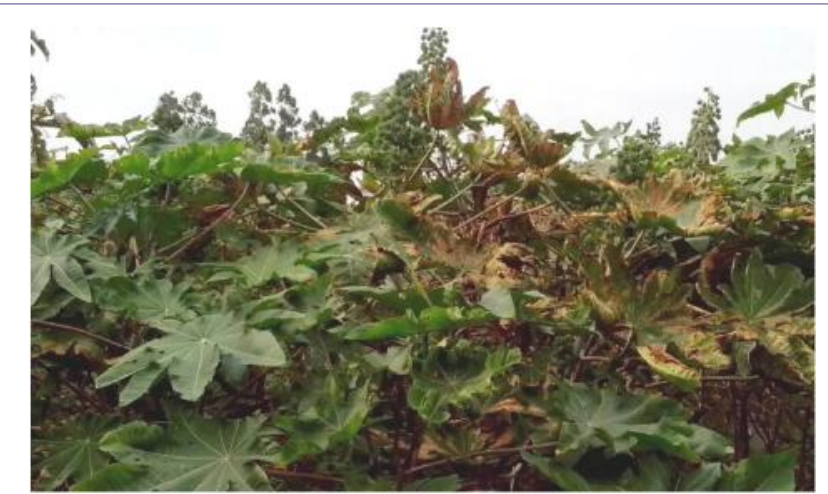

Figure 8: Image showing the resistance segregation in an $\mathrm{F}_{2}$ population derived from the resistance-susceptible combination in Guangdong Ocean University (China).

\section{Acknowledgement}

This paper was supported by the following funds: National Natural Science Foundation of China (31271759); Guangdong Provincial Science and Technology Projects (2013B060400024, 2014A020208116, 2016A020208015) (China); Project of Enhancing School with Innovation of Guangdong Ocean University (GDOU2013050206) (China).

\section{References}

1. Ramanjaneyulu AV, Anudradha G, Ramana MV, Reddy AVV, Gopal NM (2017) Multifarious Uses of Castor (Ricinus communis L.). International Journal of Economic Plants 4: 170-176.

2. Sujatha M, Devi PSD, Reddy TP (2011) Insect Pests of Castor (Ricinus communis L) and their Management Strategies. Pests and Pathogens : Management Strategies 177-198.

3. Anjani K (2012) Castor genetic resources: A primary gene pool for exploitation Industrial Crop and Products 35: 1-14.

4. Mubofu EB (2016) Castor oil as a potential renewable resource for the production of functional materials. Sustainable Chemical Process 4: 11.

5. Vivodík M, Balážová Z, Gálová Z (2014) RAPD Analysis of Genetic Diversity of Castor Bean. World Academy of Science, Engineering and Technology, International Journal of Biological, Biomolecular, Agricultural, Food and Biotechnological Engineering 8: 7.

6. Ogunniyi DS (2006) Castor oil: a vital industrial raw material. Bioresource Technology 97: 1086-1091.

7. Shridhar BS, Beena KV, Anita MV, Paramjeet KB (2010) Optimization and characterization of castor seed oil. Leornard J Sci 17: 59-70.

8. Kumar PK, Chakravarthy AK, Khan KH (2017) Biology of Castor Shoot and Capsule Borer, conogethes punctiferalis Guenee on Castor (Ricinus communis L.). International Journal of Science, Environment and Technology 6: 1134-1139.

9. Rao MS, Rama Rao CA, Srinivas K, Pratibha G, Vidya Sekhar SM, et al. (2012) Intercropping for management of insect pests of castor, Ricinus communis, in the semi-arid tropics of India. J Insect Sci 12: 14.

10. Rai BK (1976) Pests of oilseed crops in India and their control. Indian Council of Agricultural Research 128: 100-121.

11. Kotle SJ (1995) Castor: diseases and crop improvement. Shipra Publications 119.
12. Lakshminarayan M, Duraimurugan P (2014) Assessment of avoidable yield losses due to insect pests in castor (Ricinus communis L.). J Oilseeds Res 31: 140-144.

13. Hegde DM (2006) Research Achievements in Castor. All India Coordinated Project on Castor, Directorate of Oilseeds Research, Indian Council of Agricultural Research, Rajendranagar, Hyderabad, India.

14. Patel BC, Patel PS, Trivedi JB, Patel SA (2015) Population Dynamics of Sucking Pest Complex of Castor (Ricinus communis Linnaeus). International Journal of Agriculture Sciences 7: 596-600.

15. Khanpara DV, Patel GM (2002) Need based plant protection and avoidable losses in hybrid castor. Indian J Ent 64: 175-184

16. Jayaraj S (1967) Studies on the resistance of castor plant (Ricinus communis L.) to the leafhopper, Empoasca flavescens (F.) (Homiptera, Jassidae). Zeitschriff fur angewandte entomologie 59: 117-126.

17. Fabricius JC (1792) Entomologia systematica emandata et aucta. Secundum classes, ordines, genera, species adjectis synonimis, locis, observationibus descriptionibus. Hafniae, : impensis Christ. Gottl. Proft 1: 896.

18. Poos FW, Wheeler HN (1943) Studies on Host Plants of the Leafhoppers of the Genus Empoasca. Technical Bulletin, Department of Agriculture, Washington DC, USA.

19. http://www.yourarticlelibrary.com/zoology/tea-green-fly-empoasca-flavescens-distribution-life-cycle-and-control/24048

20. Saha D, Mukhopadhyay A (2013) Insecticide resistance mechanisms in three sucking insect pests of tea with reference to North-East India: an appraisal. International Journal of Tropical Insect Science 33: 46-70.

21. Jayasimha GT, Rachana RR, Manjunatha M, Rajkumar VB (2012) Biology and seasonal incidence of leafhopper, Amrasca biguttula (Ishida) (Hemiptera: Cicadellidae) on okra. Pest Management in Horticultural Ecosystem 18: 149-153.

22. Srinivasan K, KrishnaKumar NK, Ramchander PR, Rao GS (1988) Seasonal Patterns of Leafhopper, Amrasca biguttula biguttula on Okra in India. International Journal of Tropical Insect Science 9: 85-88.

23. DeLong D M (1971) The bionomics of leafhoppers. Annual Review of Entomology 16: 179-210.

24. Singh TVK, Singh KM, Singh RN (1990) Groundnut pest complex: IV. Regression studies to determine the association between jassid and thrips and weather parameters. Indian J Ent 52: 693-701.

25. Jena BC, Kuila B (1996) Jassid infestation in groundnut and its chemical control Indian J Ent 58: 378-381.

26. Laxman G, Maheswari TU (2017) Effect of Dates of Sowing on Incidence of Leaf Hoppers, Empoasca flavescens Fab. on Castor Genotypes. Int J Curr Microbiol App Sci 6: 431-437.

27. Akashe VB, Indi DV, Patil SR, Jadhav JD, Pawar PB (2015) Incidence of insect pest damage in castor in relation to meteorological parameters in the scarcity zone of Maharashtra. Journal of Agrometeorology 17: 139-141.

28. Jayaraj S, Basheer M (1964) Biological observations on the castor leafhopper, Empoasca flavescens (F) (Jassidae: Homoptera). Madras Agricultural Journal 51: 89-90.

29. Jayaraj S (1966) Influence of sowing times of castor varieties on their resistance to the leafhopper, Empoasca flavescens (homoptera, jassidae). Entomological Experimental Application 9: 359-368.

30. Lakshminarayana M, Raoof MA (2005) Insect pests and diseases of castor and their management. Directorate of Oilseeds Research, Hyderabad.

31. An Institutional Repository of Indian National Agricultural Research System (1991) Annual Progress Report: Castor-1991. Directorate of Oilseeds Research, Rajendra Nagar, Hyderabad, India. 
32. Mounica B, Venkateswarlu NC, Krishna TM, Sudhakar P, Prasad KVH (2018) Screening of Castor Genotypes for Resistance Against Green Leafhopper, Empoasca flavescens Fabricius. Int J Pure App Biosci 6: 110-116.

33. Jian-guo Z, Rong-ping K, Ke-ming H, Tao T, Qi-zhong Z (1993) The Development,Reproduction and Spatial Distribution of Lesser Green Leafhopper (Empoasca flavescens) on Different Tea Cultivars. Zoological Research 14: 241-245.

34. Widayat W, Winasa IW (2006) Bioecology of Empoasca flavescens and its natural enemy. Journal of Research of Kina and Tea 9: 12-19.

35. Zeiss MR, Braber KD (2001) Tea IPM Ecological Guide. CIDSE, Brussels, Belgium.

36. Gaur RK (2014) Diversity of insect pests of castor, Ricinus communis L and their ecological interaction in south-west Haryana. International Journal of Farm Sciences 4: 147-152.

37. Painter RH (1968) Insect Resistance in Crop Plants. Lawrence, Kansas : The University Press of Kansas 520: 973.

38. Lakshminarayana M (2003) Host plant resistance in castor against major insect pests. National Seminar on Stress Management in Oilseeds for Attaining Self-reliance in Vegetable Oils, Hyderabad, India.

39. Dorairaj MS, Savithri A, Aiyadurai SG (1963) Population density as a criterion for evaluating varietal resistance of castor (Ricinus communis L.) to jassid infestation. Madras Agricultural Journal 50: 100.

40. Shilpakala V, Krishna TM (2016) Screening of Castor Germplasm against Leafhopper and Capsule Borer. International Journal of Research in Applied, Natural and Social Sciences 4: 83-88.

41. Sheshadri CR, Sheshu KA (1956) Observations on jassid injury in castor. Madras Agric J 197-199.

42. Brar KS, Sandhu GS, Labana KS (1977) Note on the resistance of some castor varieties to Empoasca flavescens and Dichocrosos punctiferalis. Indian J Agri Res 11: 48-50.

43. Jayaraj S (1968) Studies on plant characters of castor associated with resistance to Empoasca flavescens Febr (Homoptera Jassidae) with reference to selection and breeding of varieties. Ind J Agric Sci 38: 1-6.

44. Srinivas RT, Lakshminarayana M, Anjani K (2000) Studies on the influence of bloom character of castor germplasm accessions on jassids and thrips infestation. National Seminar on Oilseeds and Oils-Research and Development Needs in the Millennium, Hyderabad, India.

45. Lakshmi PV, Satyanarayana J, Singh H, Ratnasudhakar T (2005) Incidence of green leafhopper, Empoasca flavescens Fab., on castor, Ricinus communis L., in relation to morphological characters and date of sowing. J Oilseeds Res 22: 93-99.

46. Narayanamma LV (2017) Effect Of Meteorological Factors Over The Incidence Of Sucking Pests In Rabi Castor, Ricinus Communis L. Life Sciences International Research Journal 4.
47. Dandin SB (2003) Handbook of sericulture technologies. Central Silk Board, Bangalore, India.

48. Rajadurai S, Thiagarajan V (2003) Mulberry sap sucking pests. Indian Silk $8: 5-8$

49. Samuthiravelu P, Suresh A, Jayaraj S (2003) Effect of Botanical and Biological control tactics against mulberry Tukra mealy bug Maconellicoccus hirsutus. National seminar on Disease and Pest Management in Sericulture, At Sericulture College, Chintamani, Karnataka, India.

50. Sakthivel N, Qadri SMH (2010) Impact of insecticides and botanicals on population build-up of predatory coccinellids in mulberry. Journal of Biopesticides 3: 85-87.

51. Sakthivel N, Balakrishna R, Ravikumar J, Samuthiravelu P, Isaiarasu L, et al. (2012) Efficacy of botanicals against jassid Empoasca flavescens F. (Homoptera: Cicadellidae) on mulberry and their biosafety to natural Enemies. J Biopest, 5: 246-249.

52. Anjani K, Raoof MA, Prasad MSL, Duraimurugan P, Lucose C, et al (2018) Trait-specific accessions in global castor (Ricinus communis L.) germplasm core set for utilization in castor improvement. Industrial Crops and Products 112: 766-774

53. Faselt J (2014) Effects of intercropping on biological control of potato leafhopper, Empoasca fabae. Entomological Society of America Annual Meeting 2014, USA.

54. Risch SJ (2005) Intercropping as cultural pest control: Prospects and limitations. Environ Manage 7: 9-14.

55. Srinivasa RM, Dharma RK, Singh TVK (2004) Impact of intercropping on the incidence of Maruca vitrata Geyer and Helicoverpa armigera Hubner and their predators on Pigeonpea during rainy and postrainy seasons. Shashpa 11: 61-70.

56. Songa JM, Jiang N, Schulthess F, Omwega C (2007) The role of intercropping different cereal species in controlling lepidopteran stemborers on maize in Kenya. J Appl Entomol 131: 40-49.

57. Zhang ZQ, Sun XL, Luo ZX, Bian L, Chen ZM (2014) Dual action of Catsia tora in tea plantations: repellent volatiles and augmented natural enemy population provide control of tea green leafhopper. Phytoparasitica 42: 595-607.

58. Rosmana A, Saranga AP, Jufri M, Rahim MD (2015) Intercropping of Rice Varieties Reduces Green Leafhopper and White Stem Borer Infestation. Indian Journal of Science and Technology 8: 141-146.

59. Lakshminarayana M, Anjani K (2009) Screening for confirmation of reaction of castor genotypes against leafhopper (Empoasca flavescens Fabr.) and capsule borer (Conogethes punctiferalis Guen.). J Oilseeds Res 26: 457-459. 